Original article

\title{
Risk assessment for varicose veins among city Police-A cross sectional study
}

\author{
Ramesh Timilsina ${ }^{\text {a }}$, Prasad M.R. ${ }^{\text {b }}$, Mubashir Angolkar ${ }^{\mathrm{c}}$, Nagaraj Patil ${ }^{\mathrm{d}, *}$ \\ ${ }^{a}$ J.N Medical College, KAHER, Belagavi, Karnataka, India \\ ${ }^{\mathrm{b}}$ Department of Cardiology, KLES Dr Prabhakar Kore Hospital \& MRC, Associate Professor, J.N Medical College, Belagavi, India \\ ${ }^{\mathrm{c}}$ Department of Public Health, J.N. Medical College, Nehru Nagar, Belagavi, India \\ d Department of Public Health, J.N Medical College, KAHER, Belagavi, Karnataka, India
}

\section{A R T I C L E I N F O}

\section{Keywords:}

Varicose veins

Risk

Police personnel

Prevalence

Occupational hazard

Health status

\begin{abstract}
A B S T R A C T
Introduction: People with overweight, standing for prolonged time, increasing age, smoking habit, heavy lifting and pregnancies in female increases risks of having varicose veins and are found common in lower limbs i.e saphenous vein.

Objective: To assess the risks of varicose vein among policemen and to assess the association between varicose vein and their designation among police of Belagavi city, Karnataka, India.

Material and methods: A cross sectional study was conducted among 150 police personnel who were working in Belagavi city. Information was collected by using questionnaire for socio-demographic, general information and symptoms. Observational checklist was used to assess signs of VV.

Results: Out of 150 participants, the mean age of participants was 39.28 years. Among them, 74.66\% were male and $25.34 \%$ were female where $77(51.30 \%)$ were Police Constable, 54 (36\%) were Head Constable, 15 (10\%) were ASI, $2(1.30 \%)$ were Inspector \& Sub Inspector respectively. The mean standing hour per day was found to be $6.69 \mathrm{~h}$ and the mean years of service was found to be 9.11 years. It was found that $14.7 \%$ of police personnel had varicose veins and $20 \%$ of them were in the risk of developing VV.

Conclusion: varicose veins has significant association with religion, designation, duration of working, income, marital status, lungs problem, DVT, cardiac infract and HTN. Similarly, risk of developing varicose vein has a significant association with marital status and duration of standing.
\end{abstract}

\section{Introduction}

Varicose veins (VV) are caused by incompetent venous valves which are abnormally dilated and tortuous in nature. This condition usually occurs in lower extremities in saphenous veins. Varicose veins can simply be a cosmetic issue or it may cause cramping pain in affected side and movement problems in lower extremities. ${ }^{1}$

The risk factors like prolonged standing, overweight, ageing, smoking, overweight, heavy lifting and pregnancy in females increases the possibility of developing VV. An increase in straining bowel movement, low fiber intake, genetic weakness in vein walls, increasing age, menopause increases the chances of developing $\mathrm{VV}^{2}$ Prevention can be done by elevating legs above the level of heart for several minutes throughout a day, walking every day to build calf muscle helps to relieve symptoms, maintaining body weight by eating healthy foods, keeping legs moving, flexing ankles timely while sitting at desk to keep the blood pumping, wearing compression stockings will support and aid the valves to keep the blood pumping out of legs etc. ${ }^{3}$

In population study, prevalence has been reported from $2 \%$ to over $20 \%$. This enormous variation results from different assessment and examination technique, different populations studied, different definitions applied and Western studies have shown that $20 \%$ population and in India about $5 \%$ population suffer from varicose veins. Compared to western population, India has less prevalence of varicose veins because most of the patients do not come to the hospital unless complications such as pain, edema and ulceration, etc. occur. ${ }^{4}$

According to National Health Service waiting lists in UK, Varicose Veins diagnosis is still considerable unmet need and similarly in India also. Especially in developing countries like India, assessment and treatment were challenging but with the advancement of medical sciences, diagnosis of venous diseases using USG, doppler study, endo venous and compression therapies etc has made better impact for identifying and treating venous disease. ${ }^{5}$

As per the WHO (2007) census, western population have $2 \%$ varicose

\footnotetext{
* Corresponding author. Department of Public Health, J. N. Medical College, KAHER, Belgaum, 590010, Karnataka, India.

E-mail addresses: Timilsinaramesh18@gmail.com (R. Timilsina), drnagaraj.patil108@gmail.com (N. Patil).
} 
vein where females have 3-4 times more than males. Eastern population have least magnitude of VV. Prevalence Statistics as per the country on varicose veins is 45 per 1000 population. Approximately, 1 in 22 was found for U S A. VV show an effect on 1 out of 2 individuals aged 50 years in India. Among total population of Bangalore, about 3-5\% suffer from venous disease, of which $10 \%$ of them has varicose veins. ${ }^{6}$

Policemen are at higher chances of getting varicose vein in light of the fact that their job requires prolonged standing for longer hours. Assessing its risk factors will help policemen to know whether they are at risk of getting VV or not and also to take preventive measures. The study has been aimed to assess risk of VV among police personnel of Belagavi city.

\section{Materials and methods}

A cross sectional study was conducted over a time period of 5 month from January to May 2021 among the police personnel working in Belagavi city, Karnataka. Ethical clearance was obtained from Institutional Ethical Committee. After explaining the need of the study, official permission to conduct study was obtained from the commissioner of police. The study population consisted of 150 policemen including both male and female, who were randomly recruited from nine different police station of Belagavi city. Sample size was calculated using $\boldsymbol{n}=$ $Z^{2} p q / d^{2}$ formula and taking $11 \%$ prevalence from Bangalore study. Those who had underwent lower limb surgery and had previous history of DVT were excluded from the study.

Participants who gave informed written consent were interviewed. Data collection procedure included interview by questionnaire and observational checklist to assess signs and symptoms. Height, weight was measured to calculate BMI. Questionnaire included demographic variables, health related information and past history of health. Demographic variables included age, sex, religion, marital status. Health related variables included height, weight, smoking, alcohol consumption, chewing tobacco, yoga practice, current medical illness, lifestyle, average standing duration per day and years of standing. Past history of health included suffering from DM, HTN, cardiac infract, angina, lungs problems, kidney problem and DVT.

The data was entered in MS excel and was analyzed using SPSS version 22. Chi square test was used to see the association between dependent and independent variable. Logistic regression and odds ratio was calculated to see the risk of varicose veins. P value $<0.05$ was considered as significant. Data were expressed in graphs, tables and charts wherever necessary.

\section{Results}

Out of 150 participants, majority $112(74.66 \%)$ were male and 38 (25.33\%) were female. Among them, 47 (31.33\%) were below 30 years of age, $30(20 \%)$ were between 30 and 40 years, $44(29.33 \%)$ were between 40 and 50 years and $29(19.33 \%)$ were between 50 and 60 years. The mean age of participants was 39.28 years. Among 150 policemen, 77 (51.30\%) were Police Constable, 54 (36\%) were Head Constable, 15 (10\%) were ASI, $2(1.30 \%)$ were Inspector \& Sub Inspector respectively. Out of 150 policemen, majority 72 (48\%) of them have to stand more than $8 \mathrm{~h}$ per day, $30(20 \%)$ have to stand $4-8 \mathrm{~h}$ /day, $27(18 \%)$ have to stand $2-4 \mathrm{~h} /$ day and $21(14 \%)$ have to stand less than $2 \mathrm{~h} /$ day. The mean standing hour per day was found to be $6.69 \mathrm{~h}$. Considering their year of service, majority 89 (59.30\%) had service more than 10 years, 45 (30\%) had service less than 5 years and 16 $(10.70 \%)$ had service between 5 and 10 years. The mean years of service was found to be 9.11 years (Table 1 ).

Majority, 143 (95.30\%) were Non-Smokers and 53 (35.3\%) were taking alcohol either on daily basis or sometimes and $29(19.3 \%)$ were taking tobacco either in smoke or smokeless form.38 (25.3\%) of participants were doing yoga for 2-3 times per week (Table no 2). On measuring the BMI of study participants, 77 (51.30\%) were Overweight,
Table 1

Socio-demographic details of the respondents $(n=150)$.

\begin{tabular}{lll}
\hline Socio-Demographic details & & Frequency (\%) \\
\hline & $<30$ & $47(31.3)$ \\
Age in years & $30-40$ & $30(20)$ \\
& $40-50$ & $44(29.3)$ \\
Gender & $50-60$ & $29(19.3)$ \\
& Male & $112(74.6)$ \\
Marital status & Female & $38(25.3 \%)$ \\
& Married & $119(79.3)$ \\
& Unmarried & $31(20.7)$ \\
Designation & Police Constable & $77(51.3)$ \\
& Head Constable & $54(36)$ \\
Job Experience & Asst. Sub Inspector & $15(10)$ \\
& Sub Inspector & $2(1.3)$ \\
Standing Duration per day (Hours) & Inspector & $2(1.3)$ \\
& & \\
& $<2 \mathrm{~h}$ & $21(14)$ \\
& $2-4 \mathrm{~h}$ & $27(18)$ \\
Years of Service (years) & $>8 \mathrm{~h}$ & $30(20)$ \\
& $<5$ years & $72(48)$ \\
& $5-10$ years & $16(10.7)$ \\
& $>10$ years & $89(59.3)$ \\
\hline
\end{tabular}

$43(28.70 \%)$ were Normal, 27(18\%) were Obese and $3(2 \%)$ were Underweight.

There was a significant association between Prevalence and duration of standing in years $(\mathrm{p}=0.016)$. Prevalence and designation $(\mathrm{p}=$ 0.003), prevalence \& religion ( $\mathrm{p}=0.004)$, marital status \& prevalence ( $\mathrm{p}=0.043)$, prevalence and HTN $(\mathrm{p}=0.047)$, Cardiac Infract \& prevalence $(p=0.016)$, prevalence \& Lungs problem $(p=0.013)$ and prevalence with DVT $(\mathrm{p}=0.001)$. There was no significant association of prevalence with sex, income, personal habits, lifestyle, yoga practice, average standing duration, suffering from DM and angina. (Table $2 \&$ Table 3).

It was seen total $44 \%$ of participants had considerable leg pain while standing, $40.7 \%$ had sensation of heavy legs in afternoon/evening, $6 \%$ participants had swelling of thigh/legs, $4.7 \%$ had permanent skin color change and only $2.7 \%$ had long standing ulceration/necrosis. Similarly, $26 \%$ of the participants had small spider like veins, $20 \%$ had dilated/ prominent vein, $12 \%$ participants had pigmentation, $10.7 \%$ had tenderness, $5.3 \%$ had ankle swelling, $4.7 \%$ had spontaneous skin scar on lower limbs and only $2 \%$ had eczema.

\section{Discussion}

In our study, we found majority 47 (31.3\%) of policeman belong to age group less than 30 years, $44(29.33 \%)$ participants belong to age group of (40-50) years, $30(20 \%)$ participants belong to age group of (30-40) years and $29(19.33 \%)$ participants belong to the age group of (50-60) years. In our study, 112 (74.66\%) males and 38 (25.33\%) females were enrolled. A study carried out in Gujarat, India in 2015 among traffic police personnel, found that $68.87 \%$ of policeman were in the age group (35-55) years. $43.62 \pm 9.85$ years was the mean age of study participants. Majority of study participants were males $(98.54 \%)$ and only $1.46 \%$ of the respondents were females. ${ }^{7}$

Our study found that $35.3 \%$ participants were alcohol consumer, $4.7 \%$ were smokers and $19.3 \%$ were chewing tobacco. Our study also found that majority of the participants were having low back pain (10\%) followed by allergy 4\%.DM, HTN and endocrinal problem was found in $1.3 \%$. Similar finding was reported in a study conducted in Chennai to see health status of traffic police personnel and found that $38.8 \%$ were alcohol consumer, $12.2 \%$ were smokers and $7.2 \%$ were chewing tobacco. Same study also found different morbidity such as half of the participants had low back pain (50.4\%), 23\% had DM and HTN, $12.2 \%$ had respiratory problems and $18.7 \%$ had skin disorders. ${ }^{8}$

Our study showed that, more than half $(51.30 \%)$ of study 
Table 2

Association of prevalence with different variables.

\begin{tabular}{|c|c|c|c|c|c|}
\hline \multirow[t]{3}{*}{ Variables } & & \multicolumn{3}{|c|}{ Prevalence of varicose veins } & \multirow{3}{*}{$\begin{array}{l}\mathrm{P} \\
\text { value }\end{array}$} \\
\hline & & \multirow{2}{*}{$\frac{\text { Absent }}{\text { Count (\%) }}$} & \multirow{2}{*}{$\begin{array}{l}\text { Present } \\
\text { Count } \\
(\%)\end{array}$} & \multirow{2}{*}{$\frac{\text { Total }}{\text { Count (\%) }}$} & \\
\hline & & & & & \\
\hline \multirow[t]{2}{*}{ Sex } & Male & $\begin{array}{l}94 \\
(83.9 \%)\end{array}$ & $\begin{array}{l}18 \\
(16.1 \%)\end{array}$ & $\begin{array}{l}112 \\
(100.0 \%)\end{array}$ & 0.404 \\
\hline & Female & $\begin{array}{l}34 \\
(89.5 \%)\end{array}$ & $\begin{array}{l}4 \\
(10.5 \%)\end{array}$ & $\begin{array}{l}38 \\
(100.0 \%)\end{array}$ & \\
\hline \multirow[t]{2}{*}{ Religion } & Hindu & $\begin{array}{l}124 \\
(87.3 \%)\end{array}$ & $\begin{array}{l}18 \\
(12.7 \%)\end{array}$ & $\begin{array}{l}142 \\
(100.0 \%)\end{array}$ & 0.004 \\
\hline & Muslim & $\begin{array}{l}4 \\
(50.0 \%)\end{array}$ & $\begin{array}{l}4 \\
(50.0 \%)\end{array}$ & $\begin{array}{l}8 \\
(100.0 \%)\end{array}$ & \\
\hline \multirow[t]{2}{*}{ Marital Status } & Unmarried & $\begin{array}{l}30 \\
(96.8 \%)\end{array}$ & $1(3.2 \%)$ & $\begin{array}{l}31 \\
(100.0 \%)\end{array}$ & 0.043 \\
\hline & Married & $\begin{array}{l}98 \\
(82.4 \%)\end{array}$ & $\begin{array}{l}21 \\
(17.6 \%)\end{array}$ & $\begin{array}{l}119 \\
(100.0 \%)\end{array}$ & \\
\hline \multirow[t]{4}{*}{ Designation } & ASI & $\begin{array}{l}8 \\
(53.3 \%)\end{array}$ & $\begin{array}{l}7 \\
(46.7 \%)\end{array}$ & $\begin{array}{l}15 \\
(100.0 \%)\end{array}$ & 0.003 \\
\hline & $\begin{array}{l}\text { Sub } \\
\text { Inspector }\end{array}$ & $\begin{array}{l}2 \\
(100.0 \%)\end{array}$ & $0(0.0 \%)$ & $\begin{array}{l}2 \\
(100.0 \%)\end{array}$ & \\
\hline & Inspector & $\begin{array}{l}2 \\
(100.0 \%)\end{array}$ & $0(0.0 \%)$ & $\begin{array}{l}2 \\
(100.0 \%)\end{array}$ & \\
\hline & $\begin{array}{l}\text { Head } \\
\text { Constable } \\
\text { Police } \\
\text { Constable }\end{array}$ & $\begin{array}{l}45 \\
(83.3 \%) \\
71 \\
(92.2 \%)\end{array}$ & $\begin{array}{l}9 \\
(16.7 \%) \\
6(7.8 \%)\end{array}$ & $\begin{array}{l}54 \\
(100.0 \%) \\
77 \\
(100.0 \%)\end{array}$ & \\
\hline \multirow[t]{2}{*}{ Smoking } & No & $\begin{array}{l}123 \\
(86 \%)\end{array}$ & $\begin{array}{l}20 \\
(14.0 \%)\end{array}$ & $\begin{array}{l}143 \\
(100 \%)\end{array}$ & 0.287 \\
\hline & Yes & $5(71.4 \%)$ & $\begin{array}{l}2 \\
(28.6 \%)\end{array}$ & $7(100 \%)$ & \\
\hline \multirow[t]{3}{*}{$\begin{array}{l}\text { Alcohol } \\
\text { Consumption }\end{array}$} & Never & $\begin{array}{l}86 \\
(88.7 \%)\end{array}$ & $\begin{array}{l}11 \\
(11.3 \%)\end{array}$ & $\begin{array}{l}97 \\
(100 \%)\end{array}$ & 0.172 \\
\hline & Sometimes & 39 (79\%) & $\begin{array}{l}11 \\
(22.0 \%)\end{array}$ & $\begin{array}{l}50 \\
(100 \%)\end{array}$ & \\
\hline & Always & $3(100 \%)$ & $0(0.0 \%)$ & $3(100 \%)$ & \\
\hline $\begin{array}{l}\text { Chewing } \\
\text { Tobacco }\end{array}$ & No & $\begin{array}{l}103 \\
(85.1 \%)\end{array}$ & $\begin{array}{l}18 \\
(14.9 \%)\end{array}$ & $\begin{array}{l}121 \\
(100 \%)\end{array}$ & 0.882 \\
\hline product & Yes & $\begin{array}{l}25 \\
(86.2 \%)\end{array}$ & $\begin{array}{l}4 \\
(13.8 \%)\end{array}$ & $\begin{array}{l}29 \\
(100 \%)\end{array}$ & \\
\hline \multirow[t]{2}{*}{ Lifestyle } & Sedentary & $\begin{array}{l}28 \\
(82.4 \%)\end{array}$ & $\begin{array}{l}6 \\
(17.6 \%)\end{array}$ & $\begin{array}{l}34 \\
(100 \%)\end{array}$ & 0.576 \\
\hline & Active & $\begin{array}{l}100 \\
(86.2 \%)\end{array}$ & $\begin{array}{l}16 \\
(13.8 \%)\end{array}$ & $\begin{array}{l}116 \\
(100 \%)\end{array}$ & \\
\hline $\begin{array}{l}\text { Presence of } \\
\text { current }\end{array}$ & No & $\begin{array}{l}104 \\
(84.6 \%)\end{array}$ & $\begin{array}{l}19 \\
(15.4 \%)\end{array}$ & $\begin{array}{l}123 \\
(100 \%)\end{array}$ & 0.564 \\
\hline $\begin{array}{l}\text { Medical } \\
\text { illness }\end{array}$ & Yes & $\begin{array}{l}24 \\
(88.9 \%)\end{array}$ & $\begin{array}{l}3 \\
(11.1 \%)\end{array}$ & $\begin{array}{l}27 \\
(100 \%)\end{array}$ & \\
\hline
\end{tabular}

participants were over-weight followed by normal weight $(28.70 \%)$. $18 \%$ participants were obese and $2 \%$ were underweight. A similar study was conducted in Russia among general Russian population and found $27.7 \%$ were over overweight and $37 \%$ were having obesity among resident who were having CVD. ${ }^{9}$

In the present study, Majority of the participants were married (79.3\%) and only $20.7 \%$ were unmarried. Nearly half of the study par-

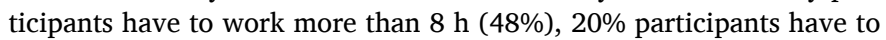
work for $4-8 \mathrm{~h}, 18 \%$ participants have to work for $2-4 \mathrm{~h}$ and $14 \%$ of the participants have to work for less than $2 \mathrm{~h}$ per day. Similar result was found in a study on work hazards and their connection with health hazard conducted among laborers working in building construction in Egypt and found that $41.1 \%$ were unmarried, 55.9\% were married and $3 \%$ were divorced/widowed. Majority of the participants $(65.5 \%)$ has more than $8 \mathrm{~h}$ working per day and $34.5 \%$ of the participants has working hour less than 8 per day. ${ }^{10}$

In our study, the risk is found to be $20 \%$. Similar result was noted in the study done in Kathmandu, Nepal, showing 12\% risk among traffic police. The overall prevalence of varicose was $14.7 \%$ in our study which is similar to the study done in Bengaluru, India showing $11 \%$ prevalence of varicose veins among traffic police ${ }^{11}$

In the present study, $10 \%$ of policemen had Muscular skeleton pain.
Table 3

Association of Prevalence with different variables.

\begin{tabular}{|c|c|c|c|c|c|}
\hline \multirow[t]{3}{*}{ Variables } & & \multicolumn{3}{|c|}{ Prevalence of varicose veins } & \multirow{3}{*}{$\begin{array}{l}\mathrm{P} \\
\text { value }\end{array}$} \\
\hline & & \multirow{2}{*}{$\begin{array}{l}\text { Absent } \\
\text { Count } \\
(\%)\end{array}$} & \multirow{2}{*}{$\frac{\text { Present }}{\text { Count (\%) }}$} & \multirow{2}{*}{$\frac{\text { Total }}{\text { Count (\%) }}$} & \\
\hline & & & & & \\
\hline $\begin{array}{l}\text { Yoga practice at } \\
\text { least } 1 \mathrm{~h} / \text { day for } \\
2-3 \text { days/week }\end{array}$ & Yes & $\begin{array}{l}97 \\
(86.6 \%) \\
31 \\
(81.6 \%)\end{array}$ & $\begin{array}{l}15 \\
(13.4 \%) \\
7 \\
(18.4 \%)\end{array}$ & $\begin{array}{l}112 \\
(100.0 \%) \\
38 \\
(100.0 \%)\end{array}$ & 0.449 \\
\hline $\begin{array}{l}\text { Average standing } \\
\text { duration (hour/ } \\
\text { day) }\end{array}$ & $\begin{array}{l}<2 \mathrm{~h} \\
2-4 \mathrm{~h} \\
4-8 \mathrm{~h}\end{array}$ & $\begin{array}{l}18 \\
(85.7 \%) \\
23 \\
(85.2 \%) \\
26 \\
(86.7 \%) \\
61 \\
(84.7 \%)\end{array}$ & $\begin{array}{l}3 \\
(14.3 \%) \\
4 \\
(14.8 \%) \\
4 \\
(13.3 \%) \\
11 \\
(15.3 \%)\end{array}$ & $\begin{array}{l}21 \\
(100.0 \%) \\
27 \\
(100.0 \%) \\
30 \\
(100.0 \%) \\
72 \\
(100.0 \%)\end{array}$ & 0.995 \\
\hline $\begin{array}{l}\text { Duration of } \\
\text { standing (in } \\
\text { Years) }\end{array}$ & $\begin{array}{l}<5 \\
\text { year } \\
5-10 \\
\text { year } \\
>10 \\
\text { year }\end{array}$ & $\begin{array}{l}44 \\
(97.8 \%) \\
12 \\
(75.0 \%) \\
72 \\
(80.9 \%)\end{array}$ & $\begin{array}{l}1(2.2 \%) \\
4 \\
(25.0 \%) \\
17 \\
(19.1 \%)\end{array}$ & $\begin{array}{l}45 \\
(100.0 \%) \\
16 \\
(100.0 \%) \\
89 \\
(100.0 \%)\end{array}$ & 0.016 \\
\hline $\begin{array}{l}\text { Suffering from } \\
\text { Diabetes } \\
\text { requiring } \\
\text { medical care }\end{array}$ & No & $\begin{array}{l}115 \\
(84.6 \%) \\
11 \\
(68.8 \%)\end{array}$ & $\begin{array}{l}21 \\
(15.4 \%) \\
5 \\
(31.3 \%)\end{array}$ & $\begin{array}{l}136 \\
(100.0 \%) \\
16 \\
(100.0 \%)\end{array}$ & 0.403 \\
\hline $\begin{array}{l}\text { Suffering from } \\
\text { Cardiac infract } \\
\text { requiring } \\
\text { medical care }\end{array}$ & Yes & $\begin{array}{l}128 \\
(85.9 \%) \\
0(0.0 \%)\end{array}$ & $\begin{array}{l}21 \\
(14.1 \%) \\
1 \\
(100.0 \%)\end{array}$ & $\begin{array}{l}149 \\
(100.0 \%) \\
1 \\
(100.0 \%)\end{array}$ & 0.016 \\
\hline $\begin{array}{l}\text { Suffering from } \\
\text { Angina requiring } \\
\text { medical care }\end{array}$ & $\begin{array}{l}\text { No } \\
\text { Yes }\end{array}$ & $\begin{array}{l}125 \\
(86.2 \%) \\
3 \\
(60.0 \%)\end{array}$ & $\begin{array}{l}20 \\
(13.8 \%) \\
2 \\
(40.0 \%)\end{array}$ & $\begin{array}{l}145 \\
(100.0 \%) \\
5 \\
(100.0 \%)\end{array}$ & 0.103 \\
\hline $\begin{array}{l}\text { Suffering from } \\
\text { lungs problem } \\
\text { requiring } \\
\text { medical care }\end{array}$ & $\begin{array}{l}\text { No } \\
\text { Yes }\end{array}$ & $\begin{array}{l}125 \\
(86.8 \%) \\
3 \\
(50.0 \%)\end{array}$ & $\begin{array}{l}19 \\
(13.2 \%) \\
3 \\
(50.0 \%)\end{array}$ & $\begin{array}{l}144 \\
(100.0 \%) \\
6 \\
(100.0 \%)\end{array}$ & 0.013 \\
\hline $\begin{array}{l}\text { Suffering from DVT } \\
\text { requiring } \\
\text { medical care }\end{array}$ & $\begin{array}{l}\text { No } \\
\text { Yes }\end{array}$ & $\begin{array}{l}128 \\
(86.5 \%) \\
0(0.0 \%)\end{array}$ & $\begin{array}{l}20 \\
(13.5 \%) \\
2 \\
(100.0 \%)\end{array}$ & $\begin{array}{l}148 \\
(100.0 \%) \\
2 \\
(100.0 \%)\end{array}$ & 0.001 \\
\hline
\end{tabular}

Similar result was found in a study conducted in Pakistan among traffic constables showing $15.9 \%$ of participants having Muscular pain. ${ }^{12}$

Our study reported that $44 \%$ of the study participants had leg pain in the evening or night and similar findings was reported by a study conducted in USA among health care workers where majority $(72.2 \%)$ of participants had leg pain in the evening. ${ }^{13}$

In this present study, the odds ratio was 0.838 \{95\% CI $(0.20-3.42)$ for female with the comparison of male. A prospective study done among Danish population reported the relative risk of $1.75\{95 \% \mathrm{CI}$ $(0.92-3.34\} .^{14}$

In the present study it was found that the average standing hour of policemen was $6.69 \mathrm{~h}$ per day and similar findings was reported in a study conducted among doctors, nurses and operation theatre assistant where their average standing duration is more than $6 \mathrm{~h}$ per day. ${ }^{15}$

In the current study, $10.7 \%$ participants had HTN and $9.3 \%$ participants had DM while the study conducted by Vijaykumar Munisami among traffic police in Tamilnadu reported $29.3 \%$ HTN which is almost thrice from our study. ${ }^{16}$

In the current study, $77.3 \%$ of study participants are regularly doing exercise and had active lifestyle while a study conducted by Hamid Shraif et al. among nurses reported only $29.77 \%$ of participants doing exercise which is less than half from our study. ${ }^{17}$

\section{Conclusion and limitation}

Our study found that $14.7 \%$ of police personnel had varicose veins 
which has significant association with religion, designation, duration of working, income, marital status, lungs problem, DVT, cardiac infract and HTN. Similarly, $20 \%$ of study participants were in the risk of developing varicose vein which has a significant association with marital status and duration of standing. Our study also concluded Muslims, ASI and Head constables, those who are not practicing yoga, those who are taking alcohol, suffering from HTN, prolonged standing, obesity and higher job experience are at risk of VV.

We did not perform USG Doppler due to Covid 19 pandemic and election being held during study period so there may be chances of missing cases of first stage varicose veins.

\section{Recommendation}

Early detection of varicose veins among police personnel can be undertaken through community initiatives. Periodic screening of varicose veins should be conducted in every police station. Similarly, Department of police service should timely arrange health education program for all police personnel about the causes and ways of preventing varicose veins with periodic rotation duty.

\section{Ethical approval}

Ethical clearance from Institutional Ethics Committee (I.E.C) of JNMC, KLE Academy of Higher Education and Research, Belagavi.

\section{Consent to participate}

Obtained.

\section{Consent for publication}

Not applicable.

\section{Funding source}

No Funding Source.

\section{Declaration of competing interest}

Authors declared no conflict of interest.

\section{Acknowledgement}

We thank all the participants, faculty members for their guidance and support in conducting this study.

\section{References}

1 Allen L. Assessment and management of patients with varicose veins. Nurs Stand. 2009 Feb 11;23(23):49.

2 Karmacharya RM, Prajapati L, Rai S. Risk assessment of varicose veins among the traffic police of Kathmandu Metropolitan City, Nepal. Indian J Vasc Endovasc Surg. 2019 Apr 1;6(2):107.

3 Tisi PV. Varicose Veins. BMJ Clinical Evidence. 2007. 2007.

4 Mohammad A, Reddy JK. Study on prevalence, demographic and clinical manifestations of lower limb vericose veins. Int J Surg Sci. 2019;3(4):272-274.

5 Pinjala R. Venous thromboembolism risk \& prophylaxis in the acute hospital care setting (ENDORSE), a multinational cross-sectional study: results from the Indian subset data. Indian J Med Res. 2012 Jul;136(1):60.

6 Renitha K, Shashidhara YN, Nayak MG. Risk factors of varicose veins among security guards. Int J Adv Res. 2015;3(3):669-674.

7 Prajapati P, Modi K, Rahul K, Kedia G. A study on sociodemographic profile and health profile of traffic police personnel of Ahmedabad city, Gujarat, India. Population Int J Health Sci Res. 2011 Oct;5:12, 18.8.

8 Satapathy D, Behera T, Tripathy R. Health status of traffic police personnel in Brahmapur City. Indian J Community Med. 2009;34(1):71-72.

9 Zolotukhin IA, Seliverstov EI, Shevtsov YN, et al. Prevalence and risk factors for chronic venous disease in the general Russian population. Eur J Vasc Endovasc Surg. 2017 Dec 1;54(6):752-758.

10 Mohamed HA. Occupational hazards and their relation with health problems among construction building workers at El Sherouk City. Am J Nurs Res. 2017;5(3):96-103, 11.

11 Radhakrishna DV. Health status of traffic police personnel: a cross-sectional study. J Med Sci Clin Res. 2016;4(12):15075-15079.

12 Butt MT, Manzoor I, Ahmad M, Shah MA. Assessment of health status of traffic constables: an occupationally exposed group in Pakistan. J Fatima Jinnah Med Univ. 2020 Mar 14;14(1):19-24.

13 Cires-Drouet RS, Fangyang L, Rosenberger S, et al. High prevalence of chronic venous disease among health care workers in the United States. J Vasc Surg: Venous and Lymphatic Disorders. 2020 Mar 1;8(2):224-230.

14 Tüchsen F, Hannerz H, Burr H, Krause N. Prolonged standing at work and hospitalisation due to varicose veins: a 12 year prospective study of the Danish population. Occup Environ Med. 2005 Dec 1;62(12):847-850.

15 Hanif A, Yousaf S, Hanif N, Murad F. Health risks among doctors, nurses and operation theatre assistants associated with their prolonged standing working hours. J Rawalpindi Med Coll. 2017;21(S-1):36-39.

16 Munisamy V. A study on socio-demographic profile and morbidity pattern of traffic policemen in an urban area of Madurai city. Tamilnadu. Nat J Res Community Med. 2019 Jun 30;8(2):103-107.

17 Sharif Nia H, Chan YH, Haghdoost AA, Soleimani MA, Beheshti Z, Bahrami N. Varicose veins of the legs among nurses: occupational and demographic characteristics. Int J Nurs Pract. 2015 Jun;21(3):313-320. 